\title{
CBS ve AHY Yöntemi Kullanılarak Bucak (Burdur/Türkiye) Mermer Atık Sahasının Belirlenmesi
}

\author{
Kerem Hepdeniz ${ }^{1}$, İbrahim İskender Soyaslan ${ }^{2 *}$ \\ ${ }^{1}$ Burdur Mehmet Akif Ersoy Üniversitesi, Bucak E.G. Tek. Bil. MYO, Mimarlık ve Şehir Planlama Bölümü, Burdur, Türkiye (ORCID: 0000-0003-4182-5570) \\ ${ }^{2}$ Burdur Mehmet Akif Ersoy Üniversitesi, Mühendislik Mimarlık Fakültesi, İnşaat Mühendisliği Bölümü, Burdur, Türkiye (ORCID: 0000-0001-5282-8094)
}

(İlk Geliş Tarihi 21 Kasım 2019 ve Kabul Tarihi 22 Aralık 2019)

(DOI: $10.31590 /$ ejosat.656601)

ATIF/REFERENCE: Hepdeniz, K., \& Soyalsan, İ., İ., (2019). CBS ve AHY Yöntemi Kullanılarak Bucak İlçesi (Burdur/Türkiye) Mermer Atık Sahasının Belirlenmesi. Avrupa Bilim ve Teknoloji Dergisi, (17), 1045-1057.

\section{Öz}

Bucak ilçesi, Türkiye’nin Batı Akdeniz bölgesinde yer alan Burdur ilinin nüfus ve ekonomi açısından en büyük ilçesidir. Burdur ili de mermer sanayisinin gelişim gösterdiği önemli iller arasında yer almaktadır. Burdur ilindeki mermer fabrika ve işletmelerinin yarıdan fazlası Bucak ilçesinde bulunmaktadır. Mermerin ocaktan çıkarılması ve fabrikada işlenmesi sonucunda, elde edilen mamul mermer dışında kalan bütün mermer parça ve tozları atık olarak kabul edilmektedir. Bu mermer atıklarının düzenli depolanma alanlarının belirlenmesi ise işletmeler açısından önemli bir sorundur. Bu makale, Bucak İlçesi’ndeki mermer atık sahası (MAS) seçiminde Analitik Hiyerarşi Yöntemi (AHY) ve coğrafi bilgi sistemleri (CBS) esaslı çok kriterli bir yer seçim çalışmasını kapsamaktadır. AHY yöntemi, karar verme kriterlerinin ağırlıklarını çift yönlü karşılaştırma yöntemiyle değerlendirir. CBS ise karar verme kriterlerinin konum analizlerinin yapıldığı bir araç olarak kullanılır. MAS yer seçiminde karar verme kriterleri olarak: Yerleşim birimleri, yollar, akarsular, kuyular, su depoları, mermer ocakları, mermer fabrikaları, eğim, arazi kullanımı ve jeoloji parametreleri kullanılmıştır. Bu parametrelerden: Akarsu, yol, yerleşim yeri, su deposu, kuyu, ocak yeri, fabrikalar, arazi kullanımı ve jeoloji haritası CBS ortamında sayısallaştırılarak hazırlanmıştır. Tüm çalışma alanını içine alan topoğrafik haritalar sayısallaştırılarak 10x10 çözünürlüğünde sayısal yükseklik modeli (SYM) haritası elde edilmiştir. SYM haritasından 9 kritere ilave olarak eğim haritası oluşturulmuştur. Tüm kriterler için mesafe analizi yapılmış ve her biri için sembol sekmesi kullanılarak sınıf aralıkları oluşturulmuştur. Bu kriterlerden sadece arazi kullanımı ve jeoloji kriterlerine mesafe analizi uygulanmamış; doğrudan raster haritasına dönüştürülmüşlerdir. Raster katmanına dönüştürülen tüm kriterler için yeniden sınıflandırma işlemi uygulanmış ve 1-6 arasında değişen sınıf aralığı değerleri atanmıştır. İkili karşılaştırma yöntemi (Pairwise comparison) kullanılarak her bir kriterin kendi arasında etki dereceleri belirlenmiş̧ir. Bu karşılaştırma sonucunda en önemli kriterin jeoloji olduğu tespit edilmiştir. Etki dereceleri ve sınıf aralık değerleri kullanılarak ağırlıklı çakıştırma analizi uygulanmıştır. Bu analiz sonucunda, çalışma sahasında "çok uygun" olarak nitelendirilebilecek alanların tüm çalışma alanı içerisinde sadece \%3,2'lik bir alanı kapladığı ve orta ve kuzeybatı kesimlerinde yoğunlaştığı belirlenmiştir.

\section{Determination of the Marble Waste Site in Bucak (Burdur / Turkey) Using GIS and AHP Method}

\begin{abstract}
Bucak province of Turkey, Burdur is located in the western Mediterranean region is the largest district of the province in terms of population and economic. Burdur is one of the important provinces where the marble industry has developed. More than half of the marble factories and enterprises in the province of Burdur are located in the district of Bucak. As a result of the extraction of the
\end{abstract}

* Sorumlu Yazar: Burdur Mehmet Akif Ersoy Üniversitesi, Mühendislik Mimarlık Fakültesi, İnşaat Mühendisliği Bölümü, Burdur, Türkiye, ORCID: 0000-0001-5282-8094, isoyaslan@gmail.com 
marble from the quarry and processing in the factory, all marble parts and dusts except the manufactured marble are considered as waste. Determining the regular storage areas of these marble wastes is an important problem for the enterprises. This paper covers a multi-criteria site selection study based on the analytical hierarchy process (AHP) and geographic information systems (GIS) in the selection of marble waste sites (MAS) in Bucak District. The AHP method evaluates the weights of decision-making criteria by a pair wise comparison method. GIS is used as a tool for the location analysis of decision-making criteria. Decision-making criteria for the selection of the marble waste area: Settlements, roads, rivers, wells, water reservoir, marble quarries, marble factories, slope, land use and geology were used. Among these parameters: River, road, settlement, water reservoir, well, quarry, factories, land use and geology map were prepared by digitizing in GIS. Topographic maps covering the entire study area were digitized and a $10 x 10$ resolution digital elevation model (DEM) map was obtained. In addition to the 9 criteria, a slope map was created from the DEM. Distance analysis was performed for all criteria and class intervals were created for each using the symbol tab. All of these criterias, were directly converted to raster maps; distance analysis was not applied to land use and geology criteria. A reclassification was performed for all criteria that were converted to a raster layer and class range values ranging from 1-6 were assigned. Pairwise comparison method was used to determine the significance of each criterion. As a result of this comparison, the most important criterion was determined as geology. Weighted overlap analysis was applied using influence grades and class range values. As a result of this analysis, "very appropriate" areas that can be characterized; covers only $3.2 \%$ of the entire study area and is concentrated in the central and northwestern parts.

(Minimum 250 - Maximum of 400 words and content should be written in a way to include material, method, findings and results.)

Keywords: Waste Area, Site Selection, AHP, GIS,

\section{Giriş}

Türkiye'nin, mermer sektörü açısından dünya rezervlerinin önemli bir kısmına sahip olduğu bilinmektedir. Yap1 çeşitliliği açısından 80' nin üzerinde, renk ve desen açısından ise 120' nin üzerinde mermer rezervi bulunmaktadır. Özellikle 1980' li yıllardan itibaren Türkiye doğal taş üretimi hızla artış göstermiş ve günümüzde üretimin tamamına yakını özel şirketler tarafından yapılmaktadır. Burdur ili Bucak ilçesi’ nin karbonat kayaçlardan oluşan Toros Karst Kuşağı üzerinde bulunması, bölgeyi mermer sektörü açısından önemli bir konuma getirmiştir. İlçenin yaklaşık $3.250 .000 \mathrm{~m}^{3}$ civarında mermer rezervi ile 60 yıllık üretim rezervi olduğu tahmin edilmektedir (Özdamar, 2001).

Özellikle 1990' ların başından itibaren bölgedeki mermer ocakları ve fabrikaları hızla artış göstermiş; 45.000 nüfusa sahip ilçede (URL-1, 2019), 40' in üzerinde mermer fabrikası açılmıştır. Bu oran istihdam açısından sektörü ilk sıraya çıkarmıştır. Son yıllarda, katma değeri yüksek olan işlenmiş ürünlerin tercih edilmesi, fabrikalarda daha fazla mermer atığının açığa çıkmasına neden olmuştur. Bucak ilçesi ve yakın çevresine bakıldığında atık malzemenin birçok alanda gelişigüzel olarak doğaya bırakıldı̆̆ı, kimi yerlerde dolgu malzemesi olarak kullanıldığı görülmektedir. Bucak ilçesinde doğaya vahşi depolama şeklinde gelişi güzel bırakılan alanların; genellikle Gündoğdu, Onaç Seydiköy ve Organize Sanayi mevkilerinde toplandığı yapılan arazi gözlemlerinde tespit edilmiştir (Soyaslan ve ark., 2011).

Katı atık depolanma alanlarının oluşturulmasındaki esas problem, uygun yer seçiminin yapılamamasıdır. Katı atık bertarafı için uygun ortamların bulunamaması, özellikle gelişmekte olan ülkelerin yerleşim alanlarının karşılaştığı en ciddi sorunlardan birisidir (Alkaradaghi ve ark., 2019).Uygun yer seçiminde ilgili yönetmeliklerle belirlenen kısıtlamalar, arazide bilgileri ve CBS programı ile daha sağlıklı bir şekilde entegre edilebilmektedir (Soyaslan ve ark., 2011). CBS, arazi kullanımı uygunluk analizleri için önemli bir araçtır. Haritalanmış görüntüler arasındaki mekânsal ilişkiyi tanıyabilir, ilişkilendirebilir ve analiz edebilir, böylece karar vericilerin farklı bilgi kaynaklarını birbirine bağlamasına, karmaşık analizler yapmasına, eğilimleri görselleştirmesine, sonuçları yansıtmasına ve uzun vadeli planlama hedefleri için strateji geliştirmesine olanak tanır (Malczewski, 2004). Aynı zamanda CBS ekonomik ve pratik bir metottur (Yazdani ver ark., 2015)

AHY olarak tanımlanan yöntem seçim kriterlerinin kendi aralarındaki ağırlık derecelerinin hesap edilmesinde kullanılmaktadır. Saaty (1980) tarafından geliştirilen AHY yöntemi karmaşık çok kriterli karar süreçleri için geliştirilmiş etkili bir araçtır. AHY yöntemi; seçim kriterlerinin belirlenmesi ve ağırlıklandırılması, toplanan verilerin analiz edilmesi ve karar alma sürecinin hızlandırılması konusunda yardımcıdır. Literatürde, AHY katı atık yeri seçimi için kabul edilen kriterlerin ağırlıklarını değerlendirmek için sıkça kullanılmıştır. Birçok bilim insanı tarafından, mevcut alternatifler arasından en uygun alanları seçmek için CBS ve AHY kombinasyonu kullanılmıştır (Alkaradaghi ve ark., 2019; Abdullah ve Adawiyah, 2014; Baiocchi ve ark., 2014; Afzali ver ark., 2014; Chabuk ve ark., 2017).

Bu makalenin amacı, AHY ve CBS kullanarak MAS seçiminde en uygun yeri belirlemektir. Bunun için atık yer seçimini etkileyeceği düşünülen on farklı kriter kullanılmıştır

\section{Materyal ve Metot}

\section{1. Çalışma Alanı}

Çalışma alanı, Türkiye'nin güney batısında, Akdeniz Bölgesi’ndeki Burdur ilinin güneyinde yer alan yaklaşık 684,41 km²'lik bir alanı kaplayan Bucak Havzası sınırları içerisindedir (Şekil 1). Bucak Havzası, Türkiye'nin önemli karst bölgelerinden biri olan Toros Karst Kuşağının Batı Toroslar kesiminde, Isparta Büklümü içerisinde yer almaktadır. 


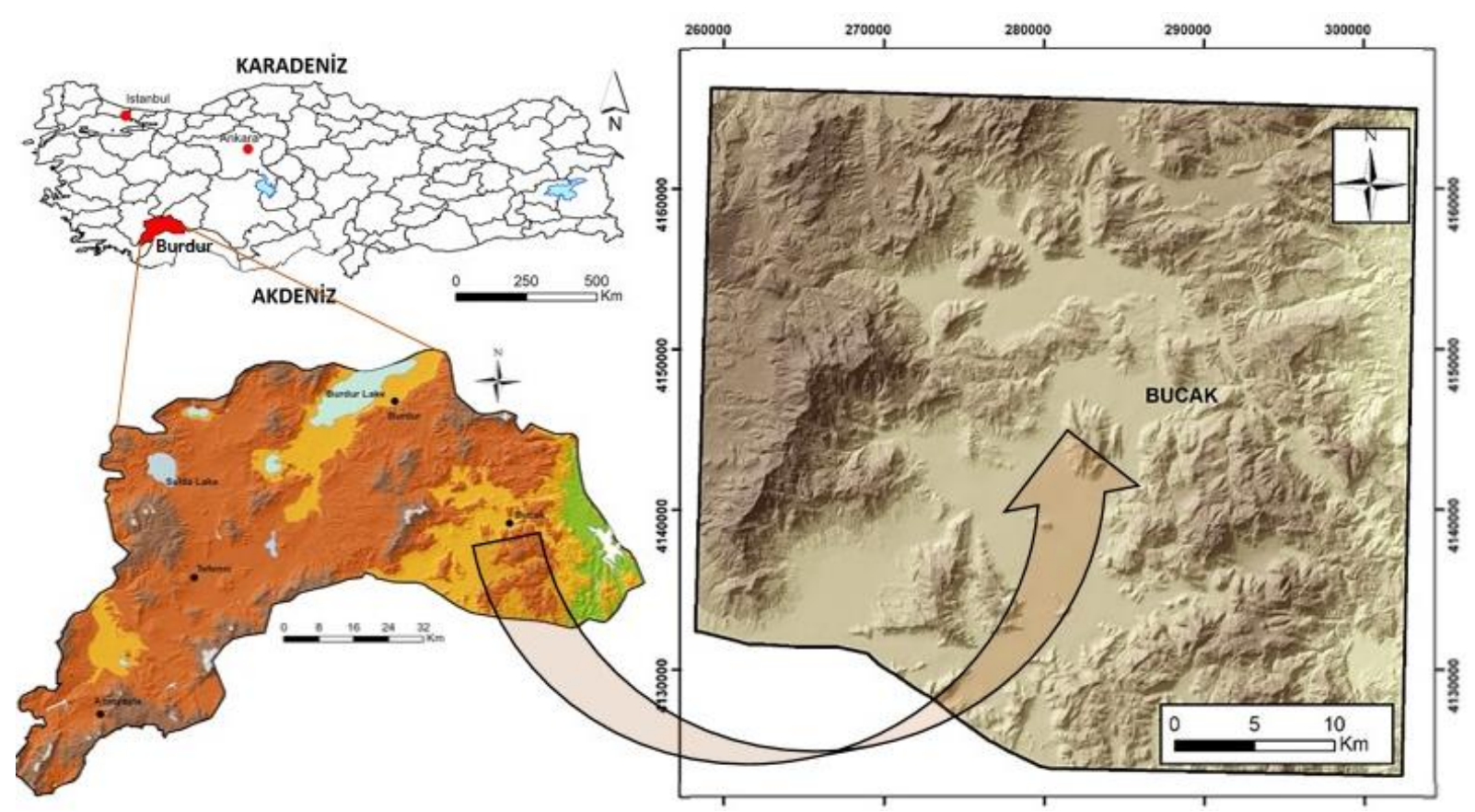

Şekil 1. Çalışma alanı yerbulduru haritası

\subsection{Mermer Atıkları ve Mevzuat}

Bu çalışmada, Bucak ilçesi çalışma alanı sınırları içerisinde bulunan mermer ocak sahaları ve fabrikalarından çıkan mermer atıklarının ilçe sınırları içerisinde depolanabileceği yerler, CBS ve AHY yöntemleri kullanılarak analiz edilmiş ve uygun yer seçimi için önerilerde bulunulmuştur. Öncelikli olarak arazide 22 adet ocak sahası incelenmiş, bu sahalarda ortaya çıkan pasa ve atık mermerler yerinde gözlemlenmiştir. İkinci aşamada ise ocaktan çıkan mermerlerin işlendiği 41 mermer fabrikasının bulunduğu organize sanayi bölgesine gidilmiş ve üretim aşamaları görüntülenmiştir. Fabrikalarda işlenen blok mermerlerden büyük oranlarda toz ve paledyen atık malzeme ortaya çıkmaktadır (TMMOB, 2014; Soyaslan ve ark., 2011).

Mermer atık sahalarının belirlenmesi için depolama sahası ile ilgili aranan kriterler ile dikkat edilmesi gereken konular Katı Atık Proje Genelgesi (KAG, 2004), Katı Atık Uygulama Projesi Genelgesi (KAUPG, 2011), Katı Atıkların Kontrolü Yönetmeliği (KAKY, 1991), Maden Atıkları Yönetmeliği (MAY, 2015), Avrupa Birliği Katı Atık Kabul Kriterleri (EC, 2009), Çevre Koruma Kurumu (EPA) (EPA, 2016), Birleşik Devletler Çevre Koruma Ajansı (USEPA, 2003) ve önceki çalışmalar (Beltran ve ark., 2010; Gorsevski ve ark., 2011; Kirimi ve Waithaka, 2014; Khan ve Samadder, 2015; Yıldırım ve Güler, 2016; Güler ve Yomralığlu, 2017; Abdulhasan ve ark., 2019; Karadağ, 2019) dikkate alınarak belirlenmiştir. Bu kriterler; akarsu, yol ağı, yerleşim yerleri, eğim, su depoları, kuyular, mermer ocak sahaları, mermer fabrikaları, arazi kullanımı ve jeoloji olmak üzere 10 kriterden oluşmaktadır. Çalışma alanı içerisinde bulunan 12 adet 1/25000 ölçekli topografik harita sayısallaştırılmış ve akarsu ağı, SYM, kuyu lokasyonları, eğim, su depoları, yerleşim yerleri bu topografik haritalardan elde edilmiştir. Jeoloji haritası ise MTA' dan elde edilen 1/100000 ölçekli haritalardan sayısallaştırılmıştır. Elde edilen tüm katmanlar, ED1950 UTM Zone 36 projeksiyon sisteminde kaydedilmiştir.

\subsection{CBS ve AHY Yöntemi}

Mekansal verilerin görüntülenmesi ve analizi için ArcGIS 10 yazılımı kullanılmıştır. Ayrıca verilerin sonuç analizine hazır hale gelebilmesi için Öklit mesafe analizi, yeniden sınıflandırma, raster dönüşümü, topoğrafik haritaların sayısallaştırılarak $10 * 10$ hücre büyüklüğüne sahip SYM haritasının elde edilmesi, bu haritadan eğim ve kabartma haritalarının üretilmesi ve ağırlıklı çakıştırma analizi gibi birçok işlem CBS ortamında gerçekleştirilmiştir. Sonuç haritasının üretilmesi için yapılan ağırlıklı çakıştırma analizinde ise katmanların kendi aralarındaki ağırlık değerlerinin belirlenmesinde ikili karşılaştırma yönteminden elde edilen değerler kullanılmıştır.

Elde edilen tematik haritaların ardından, seçilen 10 adet parametrenin kendi aralarındaki ağırlık derecelerinin hesap edilebilmesi için Saaty (1980) tarafından geliştirilen AHY kullanılmıştır. Bu amaçla, 10 adet kriter için ikili karşılaştırma matrisi oluşturulmuş ve kriterler arasında 1/9 ila 9 arası bir ölçek kullanılarak değerlendirme yapılmıştır.

Elde edilen her kritere, kendi içerisinde 1' den 6' ya kadar uygunluk puanları verilerek değerlendirilmiştir. (Tablo 1). "1" puan verilen yerler uygun olmayan depolama alanlarını, " 6 " puan verilen yerler ise en uygun alanları göstermektedir (Şengün, Siler, \& Engin, 2018). Uygunluk derecesinin göreceli olması, ortaya çıkan modelinde kısmen göreceli olmasına neden olmaktadır. Bu nedenle sonuç, kullanılan yöntem ve kriterlere bağlı olarak çeşitlilik gösterebilmektedir (Küçükönder ve Karabulut, 2007; Sancar, 2000). 
European Journal of Science and Technology

Tablo 1. Ağırlıklı Çakıştırmada Kullanılan Uygunluk Değerleri

\begin{tabular}{c|c}
\hline Ăğırlık Puanları & Uygunluk Değerleri \\
\hline 6 & En uygun \\
\hline 5 & Çok uygun \\
\hline 4 & Uygun \\
\hline 3 & Orta uygun \\
\hline 2 & Biraz uygun \\
\hline 1 & Uygun değil \\
\hline
\end{tabular}

Yapılan çalışmada “ağırlıklandırılmış doğrusal kombinasyon” (Weighted Linear Combination) yöntemi kullanılarak uygun alanlar tespit edilmiştir. Bu sistem, çoklu kriterler kullanan konularda nihai değerlerin hesaplanmasında yaygın olarak kullanılmaktadır (Randazzo ve ark., 2018; Şener, 2004; Al-Hanbali ve ark., 2011). Bu sistemin matematiksel formül olarak gösterimi ise aşağıda belirtilen eşitlik kullanılarak hesaplanmaktadır (Yoon ve Hwang, 1995).

$$
v_{i}=\sum_{i=1}^{n} w_{i} * v_{\text {ij }}
$$

Vi: Alan için uygunluk indeksi,

wj: Kriterlere verilen ağırlığın göreceli önemi,

vij: j verisine karşıllk gelen i' inci alternatif skoru.

Faktör ağırlıklarının hesaplanmasında analitik hiyerarşi yöntemi tercih edilmiştir. AHY yöntemi temel olarak, çok boyutlu önlemleri tek bir öncelik ölçeğinde birleştirerek, çeşitli karar seçeneklerine öncelik tanıma ve / veya nitel ve nicel değerlendirmelerle karakterize edilen kriterleri ilişkilendirmeye izin verir (Saaty, 1980). Bu işlem karşılıklı ikili karşılaştırma (pairwise comparison) yöntemi kullanılarak gerçekleştirilmiştir. Normalize edilmiş ağırlık değeri; karar alma aşamasında kullanılan farklı kriterlerin dereceli önemlerinin veya öncelik değerlerinin belirlenmesine dayanmaktadır (Yılmaz, 2005). Kriterlerin ikili karşılaştırmaları yapılarak bulunan tablo yer seçimini etkileyen faktörlerin dereceli önemlerini karşılaştırmak amacıyla kullanılmaktadır. Karşılaştırma 1/9' ile (en düşük öneme sahip) 9 (en fazla öneme sahip) arasında değişen devamlı bir ölçek kullanılarak gerçekleştirilmektedir (Siddiqui ve ark., 1996; Alanbari ve ark., 2014; Vasiljevic ve ark., 2012). (Tablo 2).

Tablo 2. İkili karşslaştırma işleminde kullanılan ölçek değerleri (Saaty, 1980)

\begin{tabular}{c|c}
\hline Önem yoğunluğu & Önem derecesi \\
\hline 1 & Eşit önemli \\
\hline 3 & Orta önemli \\
\hline 5 & Önemli \\
\hline 7 & Çok önemli \\
\hline 9 & Oldukça önemli \\
\hline $2,4,6,8$ & İki yakın karar arasındaki ara değerler \\
\hline
\end{tabular}

Her bir faktörün önemi, çalışma alanının yerel durumuna bağlı olarak değişkenlik gösterebilir. Bu nedenle, göreceli önem düzeyinin seçimi, çalışma alanının yerel koşullarına uygun olmalıdır. Bu ikili karşılaşıırma, her bir faktörün katkısının bağımsız bir şekilde değerlendirilmesine olanak sağlayarak karar alma sürecini kolaylaştırmıştır (Rezaei-Moghaddam ve Karami, 2008). Kullanılan bu yöntem sayesinde elde edilen sonuç haritası, karar vericilere "en uygun" ile "uygun değil" arasında değişen çeşitli seçenekler sunabilmektedir.

İkili karşılaştırma yönteminin güçlü yönlerinden biri, verilen puanlama neticesinde tutarlılık endeksi (CI) ile derecelendirme tutarsızlıklarının belirlenebilmesidir.

$$
\mathrm{CI}=\frac{\lambda \max -\mathrm{n}}{\mathrm{n}-1}
$$

CI: Tutarlılık endeksi, $\lambda$ max: maksimum özdeğer (eigen) ve n: karşılaştırma matriksinin sıralamasını verir (Ying ve ark., 2007). Matris değerlerinin oluşturulması ile maksimum özdeğer $(\lambda \max )$ 11,1560 olarak hesaplanmıştır. Sonrasında CI, Rastgele endeksi (RI:Random index) olarak tanımlanan standart düzeltme değerine bölünerek Tutarlılık oranı (CR: Consistency rate) değeri elde edilir.

$$
\mathrm{CR}=\frac{\mathrm{CI}}{\mathrm{RI}}
$$

CR sayısının 0.1' den kü̧̈ük olması, oluşturulan matrisin tutarlı olduğunu göstermektedir. Karşılaştırmada 10 adet kriter kullanıldığı için RI: 1,49 olarak alınmıştır (Saaty, 1980). 


\section{Araştırma Sonuçları ve Tartışma}

\subsection{Yer Seçiminde Kullanılan Kriterler}

\subsubsection{Yerleşim Birimleri}

Çalışma alanı içerisinde en büyük yerleşim merkezi Bucak ilçesidir. Bucak Kaymakamlığı 2016 yılı nüfus sayımı verilerine göre 44.086 ilçe merkezi; 20.821 kır kesiminde olmak üzere toplam nüfusu 64.910' dır (URL-1, 2019). Son 45 yıl içerisinde ilçe nüfusunun yaklaşık 2 kat arttığı görülmektedir. Çalışma alanı içerisinde ise başta Bucak ilçe merkezi olmak üzere toplamda 75 ilçe, köy, ve mahalle mevcuttur ve bu yerleşim alanları, çalışma sınırı içerisinde homojen bir dağılım göstermektedir. Yerleşim sahalarına yakın kurulan katı atık depolama alanları gürültü, estetik, hijyen, toz ve koku açısından olumsuz etkiler yaratır. Mermer atıkları açısından ise tek fark, atıkların herhangi bir koku yaymamasıdır. Yapılan çalışmalarda, depolama alanının yerleşim yerine uzaklığı konusunda farklı mesafe aralıklarının kullanıldığı görülmüştür. Allen, ve diğerlerine göre bir depolama sahası yerleşim yerlerinden en az 5000 metre ve müstakil evlerden ise en az 500 metre uzakta olmalıdır (Allen, 2002; Allen ve ark., 2002). Siddiqui ve ark., (1966) göre ise 10 ve daha fazla evden oluşan bir yerleşim yerine en yakın depolama alanı, 0.4 kilometreden daha yakın olmamalıdır (Siddiqui ve ark., 1996). Önerilen tüm emniyet mesafeleri göz önünde bulundurularak, Katı Atıkların Kontrolü Yönetmeliği'nde belirtilen “depolama alanlarının, en yakın yerleşim bölgesine uzaklığı 1000 metreden az olan yerlerde inşa edilemez" ifadesi dikkate alınarak minimum mesafe değeri olarak 1000 metre kabul edilmiştir. Bu mesafe yerleşim bölgeleri çevresinde tampon bölgeler oluşturmak için kullanılmıştır. Depolama sahaları için kesinlikle uygun olmayan alanlar 1 puan ve en uygun alanlar 6 puan verilerek uygunluk sınıflarına ayrılmışlardır (Tablo 3; Şekil 1).

\section{Tablo 3. Yerleşim alanlarına olan mesafeler ve ă̆ırlık değerleri}

\begin{tabular}{c|c|c}
\hline Mesafe (metre) & Ăğırlık Değeri & Açıklamalar \\
\hline$<1000$ & 1 & Uygun değil \\
\hline $1000-1300$ & 2 & Biraz Uygun \\
\hline $1300-1600$ & 3 & Orta Uygun \\
\hline $1600-1900$ & 4 & Uygun \\
\hline $1900-2200$ & 5 & Çok Uygun \\
\hline$>2200$ & 6 & En uygun \\
\hline
\end{tabular}

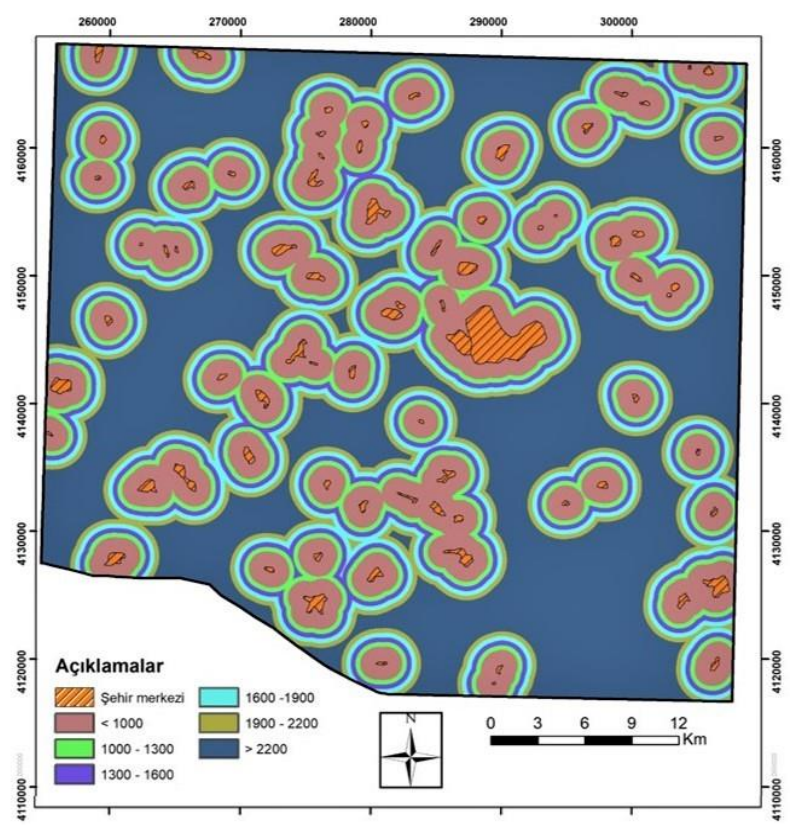

Şekil 1. Çalışma alanındaki yerleşim alanlarının ă̆ırlık dĕgeri haritası

\subsubsection{Yollar}

Çalışma alanı içerisinde Burdur ve Antalya illerini bağlayan devlet karayolu en önemli ulaşım hattını oluşturmaktadır. Devlet yollarının haricinde, sokak, cadde, ana arter ve köy yolları da sayısallaştırılmıştır. Depolama alanı belirlenmesi için, en iyi mesafenin ne olması gerektiğine dair bir fikir birliği yoktur. Depolama alanının yollardan 1 km' lik bir tampon içinde yer alması gerektiğini ileri süren çalışmalar olduğu gibi (Baban ve Flannagan, 1998; Chang ve ark., 2008; Delgado ve ark., 2008) depolama sahası bağlantı yollarının inşa edilmesinin maliyetinden kaçınmak için mevcut yol ağlarından çok uzağa yerleştirilmemesini belirten çalışmalarda mevcuttur (Lin ve Kao, 1999). Lunkapis ve ark., (2002) ise; 100 metreden daha yakın yol güzergahlarına depolama sahası inşa edilmemesi gerektiğini vurgulamışlardır (Lunkapis ve ark., 2002). Bu çalışmada ise Katı Atık Yönetmeliğinde belirtildiği şekilde 100 metreden daha yakın mesafeler, uygun olmayan alanlar olarak belirtilerek 1 puan verilmiş; 1000-1300 metre arasındaki mesafenin ise ekonomik koşullar dikkate alınarak en uygun değere sahip olduğu 6 puan verilmiş ve haritalaması yapılmıştır (Tablo 4; Şekil 2). 
Tablo 4. Yollara olan mesafeler ve ă̆ırlık değerleri

\begin{tabular}{c|c|c}
\hline Mesafe (metre) & Ağırlık Değeri & Açılamalar \\
\hline$<100$ & 1 & Uygun değil \\
\hline $100-400$ & 2 & Biraz Uygun \\
\hline $400-700$ & 3 & Orta Uygun \\
\hline $700-1000$ & 4 & Uygun \\
\hline $1000-1300$ & 6 & En Uygun \\
\hline$>1300$ & 5 & Çok uygun \\
\hline
\end{tabular}

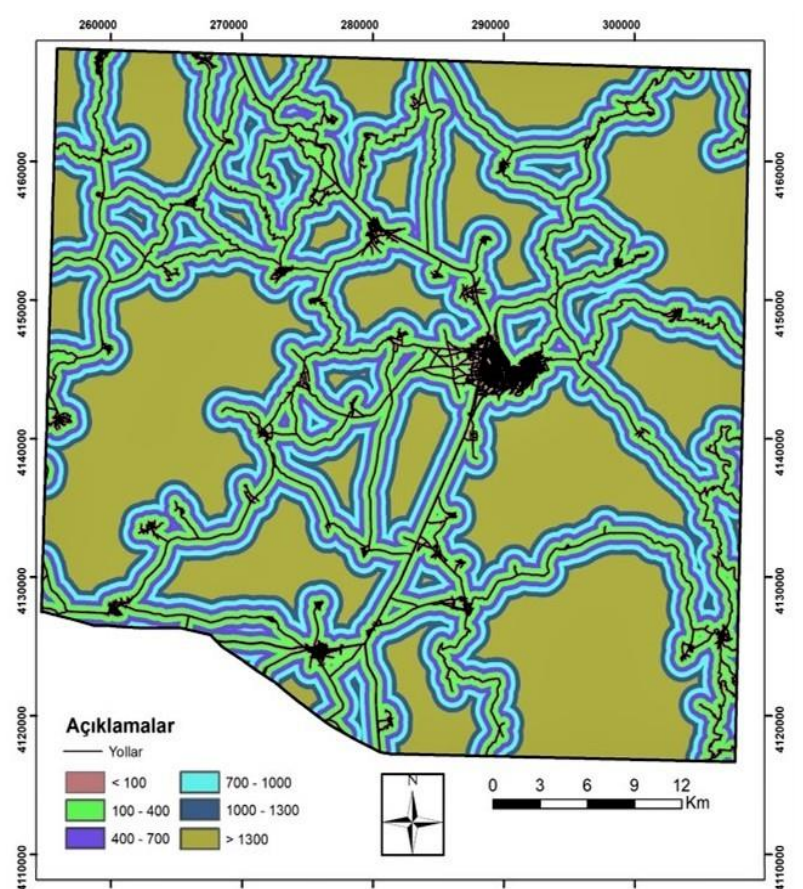

Şekil 2. Çalışma alanındaki yolların ă̆ırlık değerleri haritası

\subsubsection{Akarsular, Kuyular ve Su Depoları}

Depolama alanları; su kaynaklarını, sızıntı ve yüzeysel akış yoluyla kirletme potansiyelleri oldukça yüksektir. Bu nedenle hidrolojik özelliğe sahip alanlara yakın olmamalıdır (Zulu ve Jerie, 2017). Bucak ilçesi ve civarındaki yüzey suyunun çoğu, kış mevsiminde şiddetli yağışlar sırasında meydana gelen akarsular şeklindedir. Bölgeye ait akarsular, kuyular ve su depolarının konumları 1/25000 ölçekli topografik haritalar ve saha gözlemleri kullanılarak belirlenmiş ve sayısallaştırma işlemi yapılmıştır. Yapılan literatür incelemesinde, mesafe katmanlarının oluşturulmasında farklı kriterlerin uygulandığı görülmüştür. Avrupa Birliği yönetmeliği, önemli su kütlelerinin çevresinde $500 \mathrm{~m}$ tampon zonun korunması gerektiğini belirtmektedir (Kontos ve ark., 2003). Katı Atık Yönetmeliğine göre ise depo, içme suyu ve yüzeysel su kaynaklarının korunması amacı ile bu bölgelere depolama alanı oluşturulamayacağı ve tampon bölgenin 100 m' de daha yakın olamayacağı belirtilmiştir (Küçükönder ve Karabulut, 2007). Mahini ve Gholamalifard (2006) ise yüzey sularına olan mesafeyi 200 ila 1000 metre aralı̆̆ında sınırlandırmışlardır (Mahini ve Gholamalifard, 2006). Bu çalışmada ise, akarsular, kuyular ve su depoları için ayrı ayrı katmanlar oluşturulmuş ancak her 3 katman için aynı mesafe ölçüleri kullanılmıştır (Tablo 5). Buna göre Öklit mesafe modülü kullanılarak, su kaynaklarına 100 metre mesafeye kadar olan alanlar uygun olmayan, 1000 metreden daha uzak alanlar ise en uygun alanlar olacak şekilde mesafe analizi uygulanmıştır (Şekil 3).

Tablo 5: Akarsu, kuyular ve su depolarına olan mesafeler ve ağırlık değerleri

\begin{tabular}{c|c|c}
\hline Mesafe (metre) & Ağırlık Değeri & Açıklamalar \\
\hline$<100$ & 1 & Uygun değil \\
\hline $100-250$ & 2 & Biraz Uygun \\
\hline $250-500$ & 3 & Orta Uygun \\
\hline $500-750$ & 4 & Uygun \\
\hline $750-1000$ & 5 & Çok Uygun \\
\hline$>1000$ & 6 & En uygun \\
\hline
\end{tabular}



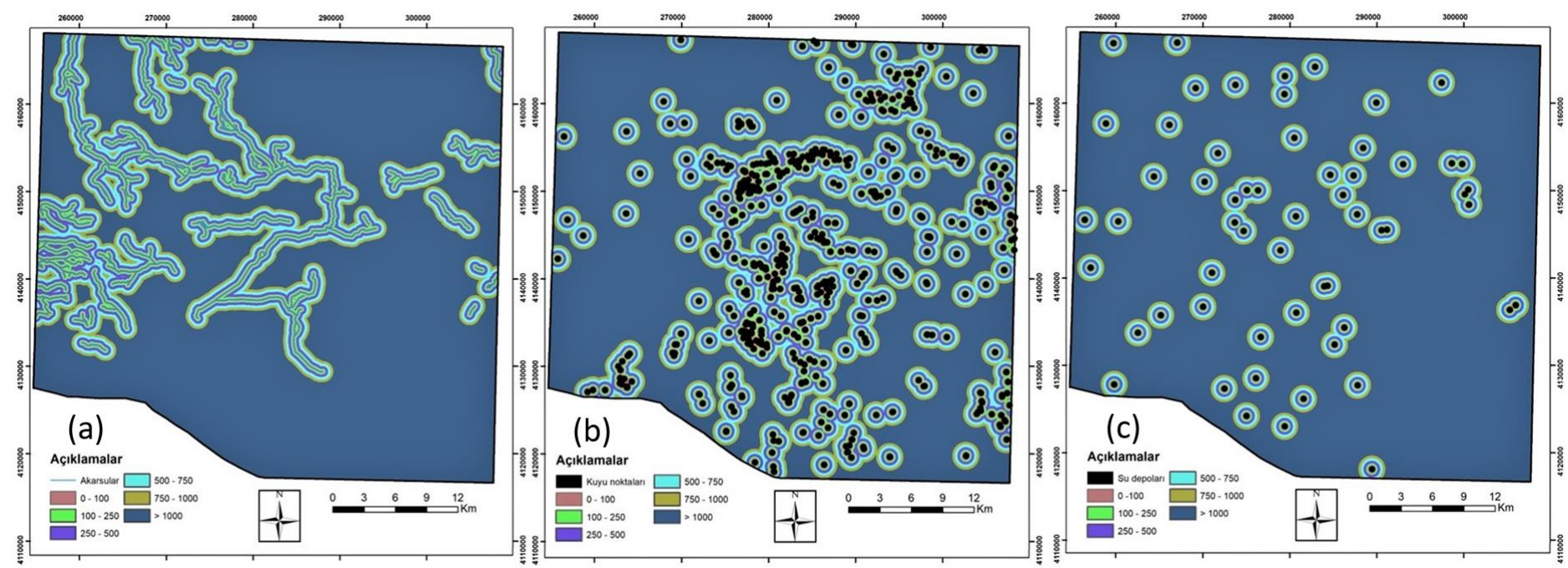

Şekil 3. Çalışma alanındaki akarsu (a), kuyular (b) ve su depolarının (c) ağırlık değerleri haritası

Tablo 6. Ocak sahaları ve fabrikalara olan mesafeler ve ă̆ırlı değerleri

\begin{tabular}{c|c|c}
\hline Mesafe (kilometre) & Ăğırık Değeri & Açıklamalar \\
\hline$>10$ & 1 & Uygun değil \\
\hline $8-10$ & 2 & Biraz Uygun \\
\hline $6-8$ & 3 & Orta Uygun \\
\hline $4-6$ & 4 & Uygun \\
\hline $2-4$ & 5 & Çok Uygun \\
\hline $0-2$ & 6 & En uygun \\
\hline
\end{tabular}

\subsubsection{Ocak Sahalart ve Fabrikalar}

Çalışma alanı içerisinde bulunan fabrikaların hemen hepsi, Bucak organize sanayi bölgesi içerisinde yer almaktadır. Ocakların ise daha çok sahanın orta ve kuzeydoğu yönünde kümelendiği görülmektedir. Dimopoulou ve ark., (2011), Yunanistan' in Drama bölgesindeki mermer atıkları için yapmış oldukları çalışmada 10 kilometreden daha uzak mesafelerde atık alanlarının belirlenmesini işletme maliyetleri için uygun olmadığını belirtmişlerdir (Dimopoulou ve ark., 2011). Çalışma sahasının benzer özellik ve büyüklüğü dikkate alınarak, bu çalışmada ocak sahaları ve fabrikalar için Tablo 6'daki mesafeler ve ağırlık değerleri dikkate alınmış ve haritalandırılmıştır (Şekil 4).
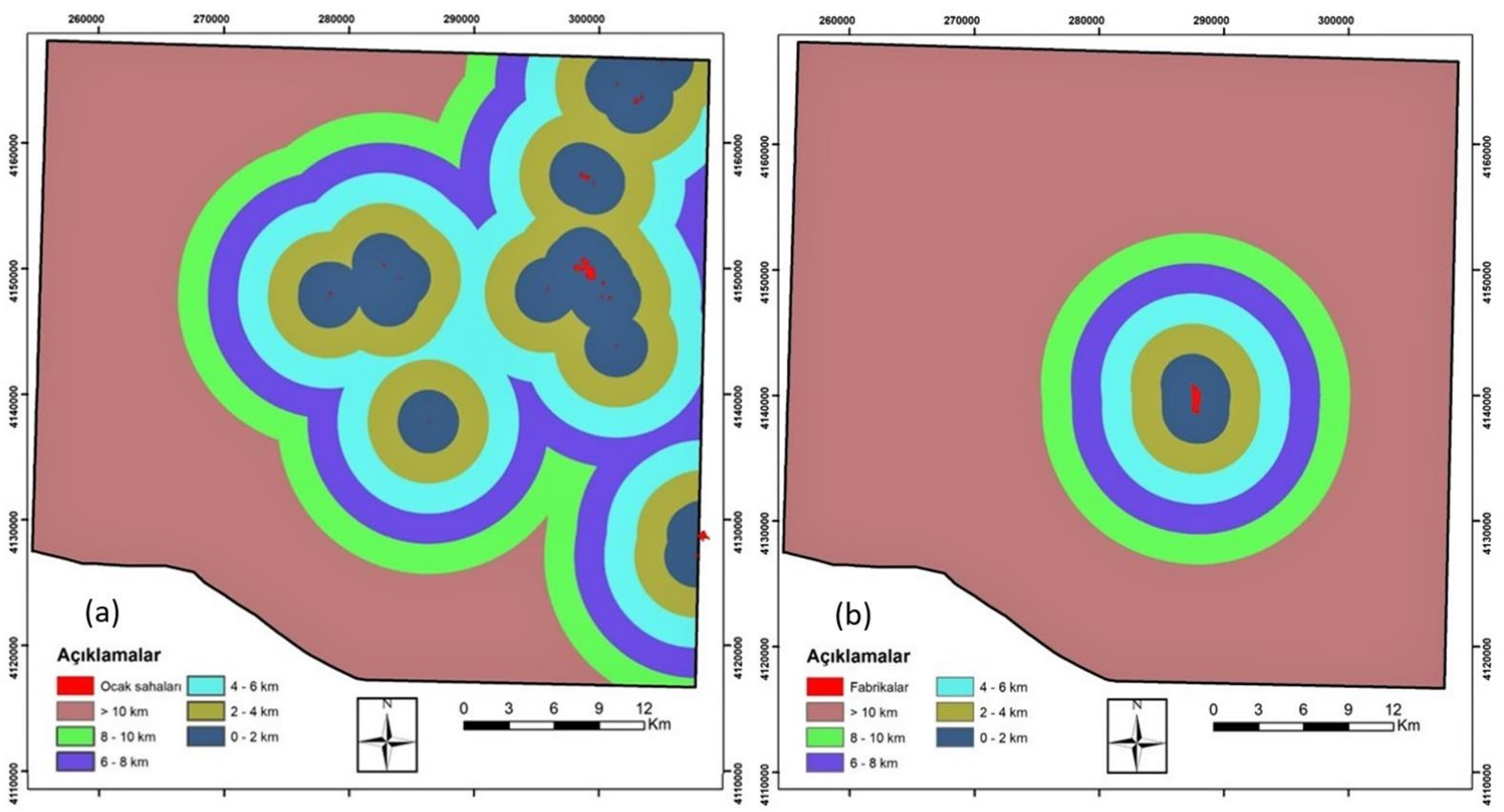

Şekil 4. Çalışma alanındaki ocak sahaları (a) ve fabrikaların (b) tampon bölgeleri haritası 


\subsection{5. Ĕ̈im}

Arazinin eğimi, depolama alanlarının belirlenmesinde temel kriterlerden biridir. Yüksek eğime sahip alanlar depolama sahası için uygun değildir (Randazzo ve ark., 2018). Lin ve Kao (1998; 1999) yapmış oldukları çalışmalarda \%12’ den daha düşük eğime sahip sahaların depolama için uygun olduğunu belirtirken, Sarptaş ve Alparslan (2008), eğimin en fazla \%15-20 arasında olması gerektiğini vurgulamışlardır. Çalışma sahası eğim haritası, 10*10 çözünürlüğe sahip SYM haritası kullanılarak elde edilmiştir. Sahada en düşük rakım 315 metre, en yüksek rakım ise 2318 metredir ve oldukça engebeli bir morfolojiye sahiptir. Dik eğime sahip alanlar ise genellikle kayalık alanlarda gözlemlenmektedir. Arazinin genel durumu ve literatür incelemeleri dikkate alınarak, eğim sınıflamaları ve ağırlık değerleri 5 sınıfa ayrılarak tablo 7'deki gibi oluşturulmuş ve haritalandırılması yapılmıştır (Şekil 5).

Tablo 7. Ĕ̈im sinuflarl ve ăgırlik değerleri

\begin{tabular}{c|c|c}
\hline Eğim sınıfları (derece) & Ağırlık Değeri & Açıklamalar \\
\hline$>20$ & 1 & Uygun değil \\
\hline $15-20$ & 3 & Orta Uygun \\
\hline $10-15$ & 4 & Uygun \\
\hline $5-10$ & 5 & Çok Uygun \\
\hline $0-5$ & 6 & En Uygun \\
\hline
\end{tabular}

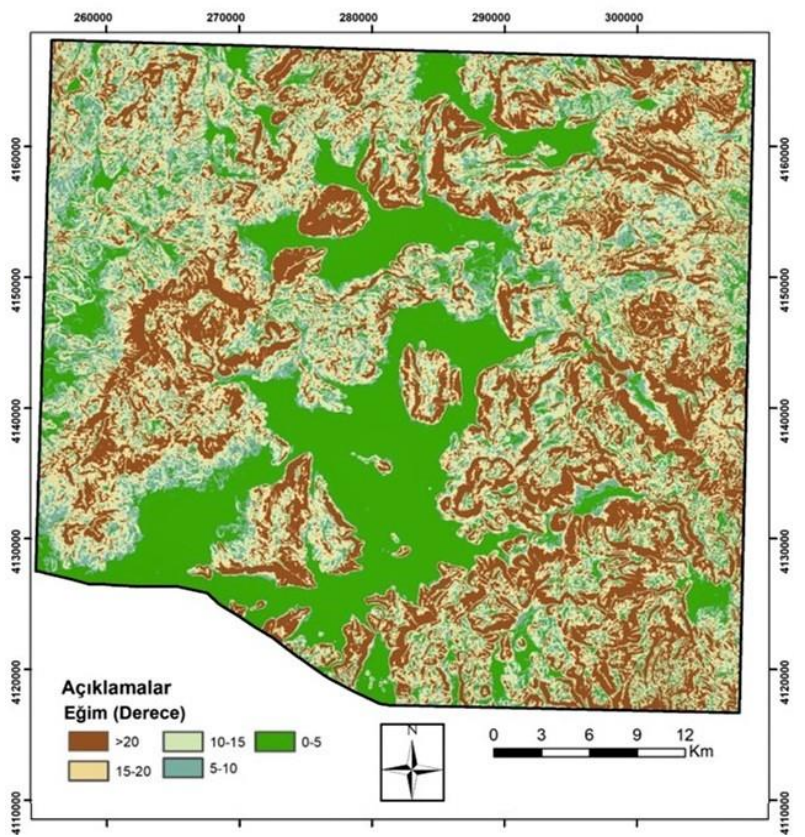

Şekil 5. Çalışma alanının ĕgim sinıfları ăgırlık değeri haritası

\subsubsection{Arazi Kullanımı}

Arazi kullanım haritası Burdur Afet ve Acil Durum Yönetimi Başkanlığı’ndan (AFAD) elde edilerek sayısallaştırılmış ve raster veri dönüşümü uygulanmıştır. Çalışma alanı içerisinde 18 arazi kullanım tipi sınıflandırılmıştır. Çalılık veya otların hakim olduğu alanlar, yoğun bitkiler ve zehirli böcekler gibi doğal rahatsızlıkların varlığından dolayı insan yerleşimi için uygun değildir. Nadasa bırakılan topraklar ve çalılık arazileri insan faaliyetlerinden uzak olduğundan, depolama alanları için en uygun bölgeler olarak kabul edilirler (Kapilan ve Elangovan, 2018). Bataklık alanları, endüstriyel ve ticari birimler, yerleşim yerleri, şehir yapıları gibi alanlar ise depolama alanına uygun olmayan yerlerdir. Tarımsal faaliyetlerin yürütüldüğü araziler yine döküm sahası olarak tercih edilmemektedir (Kontos ve ark., 2005). Sahada bulunan 18 ayrı arazi kullanım tipine göre, literatür taramaları da göz önüne alınarak Tablo 8'deki ağırlık değerleri verilerek haritalandırılması yapılmıştır (Şekil 6). 
European Journal of Science and Technology

Tablo 8.Arazi kullanımı ve ă̆ırlık değerleri

\begin{tabular}{c|c|c}
\hline Arazi kullanımı & A ğırlık Değeri & Açıklamalar \\
\hline Şehir yapısı & 1 & Uygun değil \\
\hline Bataklık & 1 & Uygun değil \\
\hline Endüstriyel ve ticari birimler & 1 & Uygun değil \\
\hline Maden çıarım sahaları & 1 & Uygun değil \\
\hline Meyva bahçeleri & 1 & Uygun değil \\
\hline Tarım alanları & 1 & Uygun değil \\
\hline Sklerofil bitki örtüsü & 2 & Biraz Uygun \\
\hline Karışık ormanlar & 2 & Biraz Uygun \\
\hline Ĭgne yapraklı ormanlar & 2 & Biraz Uygun \\
\hline Geniş yapraklı ormanlar & 2 & Biraz Uygun \\
\hline Bitki değişim alanları & 2 & Biraz Uygun \\
\hline Doğal bitki örtüsü ile bulunan tarım alanları & 2 & Biraz Uygun \\
\hline Sürekli sulanan alanlar & 2 & Biraz Uygun \\
\hline Seyrek bitki alanları & 3 & Orta Uygun \\
\hline Sulanmayan ekilebilir alanlar & 3 & Orta Uygun \\
\hline Doğal çayırlık & 4 & Uygun \\
\hline Meralar & 5 & Cok Uygun \\
\hline Çıplak kayalıklar & 6 & En Uygun \\
\hline & &
\end{tabular}

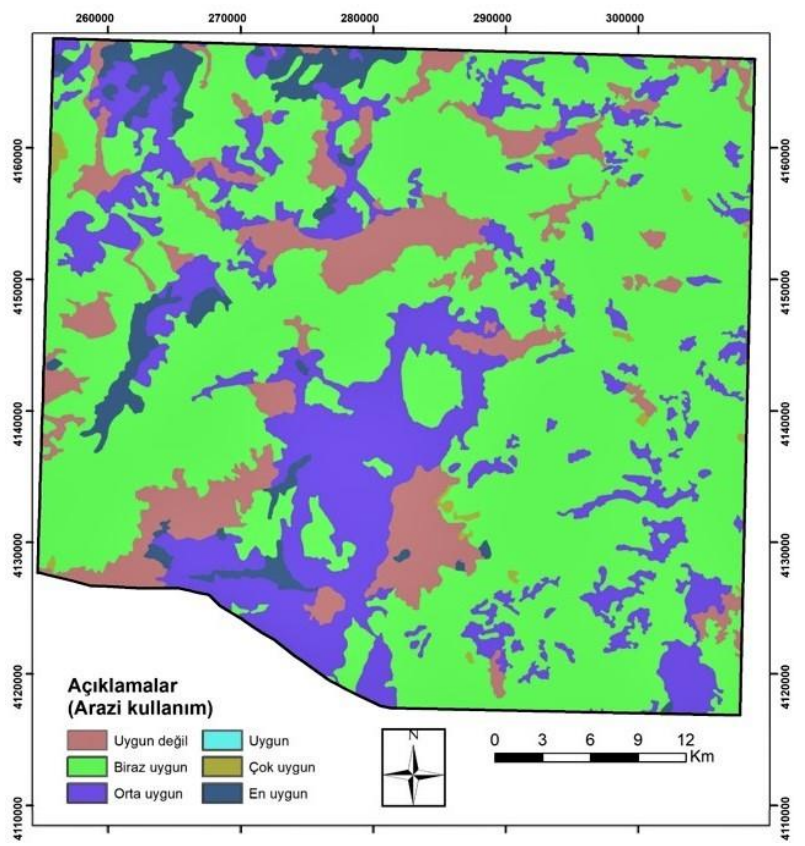

Şekil 6. Çalı̧̧ma alanının arazi kullanımı ă̆ırlık değeri haritası

\subsubsection{Jeoloji}

Çalışma alanına ait jeoloji haritası Burdur AFAD' dan elde edilerek sayısallaş̧ııılmış ve raster veri dönüşüm işlemi gerçekleştirilmiştir. Depolama alanı için belirlenecek bölgenin, litolojik açıdan geçirimsiz olması aranan en önemli özelliktir. Bu sebeple, birimlere ağırlık değerleri verilirken kayaçların geçirimlilik düzeyleri ile kırık çatlak özellikleri ön planda tutulmuştur. Saha içerisinde 16 litoloji türü ayırt edilmiş ve her birine ait ağılık değerleri Tablo 9'da verilerek haritalandırılması yapılmıştır (Şekil 7 ). 
European Journal of Science and Technology

Tablo 9. Jeolojik birimler ve ăgırlı değerleri

\begin{tabular}{c|c|c}
\hline Jeolojik birimler & Ă̆ırlık Değeri & Açıklamalar \\
\hline Alüvyon & 1 & Uygun değil \\
\hline Alüvyon yelpazesi & 1 & Uygun değil \\
\hline Eski alüvyon & 1 & Uygun değil \\
\hline Traverten & 1 & Uygun değil \\
\hline Yamaç molozu & 1 & Uygun değil \\
\hline Kireçtaş1 & 2 & Biraz Uygun \\
\hline Kumtaş1-Çamurtaş1 & 2 & Biraz Uygun \\
\hline Kumtaş1-Çamurtaş1-Kireçtaş1 & 2 & Biraz Uygun \\
\hline Volkanit-Çökel kaya & 2 & Biraz Uygun \\
\hline Çakııltaş1 & 2 & Biraz Uygun \\
\hline Çakıltaş1-Kumtaş1-Çamurtaş1 & 2 & Biraz Uygun \\
\hline Olistostrom & 3 & Orta Uygun \\
\hline Dolomit & 5 & Çok Uygun \\
\hline Melanj & 5 & Çok Uygun \\
\hline Çört & 5 & Çok Uygun \\
\hline Traki bazalt & 6 & En Uygun \\
\hline
\end{tabular}

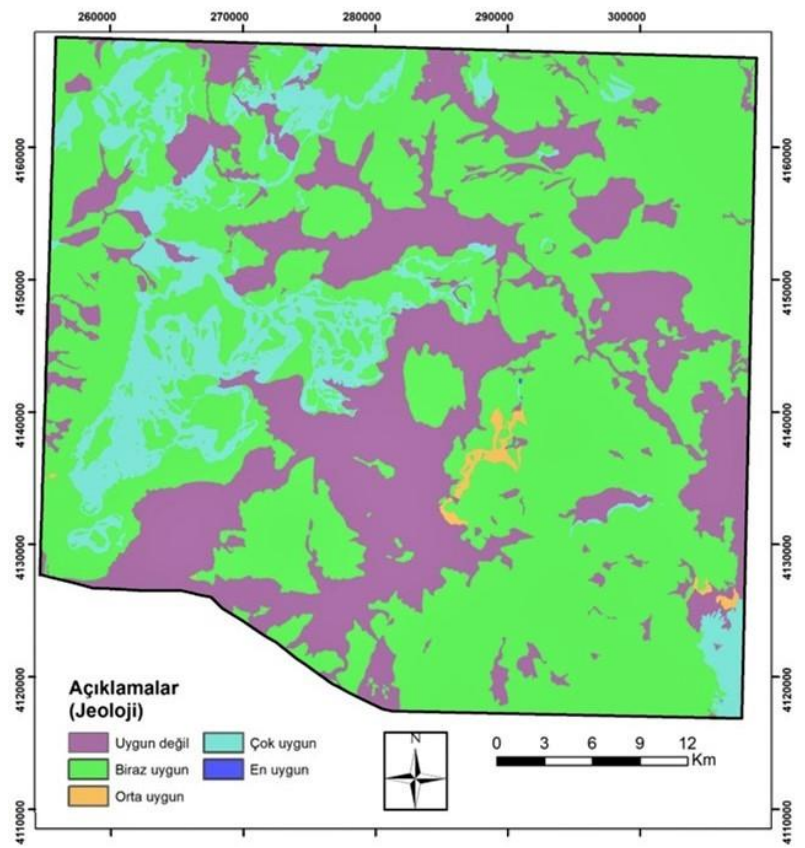

Şekil 7. Çalışma alanındaki jeolojik birimlere ait ăğrlık değerleri haritası

\section{2. İkili Karşılaştırma Yöntemi ve Ağırlıklı Çalıştırma Analizi}

AHY yöntemi kullanılarak 10 farklı kriter için ikili karşılaştırma matrisi ve kriterlerin kendi içinde 1/9-9 arasında ölçekle yapılan değerlendirme sonucunda elde edilen değerler tablo 10'da verilmiştir. Tabloda verilen değerlerden; 1 farksızlık veya eşit öneme sahip, 9 aşırı tercih veya mutlak önem, 1/9 ise kriterin önemsiz olduğunu ifade etmektedir.

Tablo 10. İkili karşılaştırma matrisi ve ă̆ırlık dĕ̆erleri

\begin{tabular}{|c|c|c|c|c|c|c|c|c|c|c|c|}
\hline & $\mathbf{A}$ & B & $\mathbf{C}$ & D & $\mathbf{E}$ & $\mathbf{F}$ & $\mathbf{G}$ & $\mathbf{H}$ & I & $\mathbf{J}$ & Ă̆ırlık Değeri \\
\hline Akarsu (A) & 1 & 7 & 5 & 0.333 & 3 & 2 & 5 & 5 & 1 & 0.333 & 0,108 \\
\hline Yol (B) & & 1 & 0.333 & 0.111 & 0.143 & 0.143 & 1 & 1 & 0.143 & 0.143 & 0,024 \\
\hline Yerleşim yeri $(\mathrm{C})$ & & & 1 & 0.200 & 1 & 1 & 4 & 4 & 0.200 & 0.200 & 0,050 \\
\hline Ĕgim (D) & & & & 1 & 4 & 4 & 7 & 7 & 3 & 1 & 0,260 \\
\hline Su deposu $(E)$ & & & & & 1 & 1 & 5 & 5 & 0.200 & 0.200 & 0,058 \\
\hline Kuyu (F) & & & & & & 1 & 5 & 5 & 1 & 0.333 & 0,077 \\
\hline Ocak yerleri $(\mathbf{G})$ & & & & & & & 1 & 1 & 0.200 & 0.200 & 0,031 \\
\hline Fabrika $(\mathbf{H})$ & & & & & & & & 1 & 0.200 & 0.200 & 0,031 \\
\hline Arazi kullanimi (I) & & & & & & & & & 1 & 0.333 & 0,108 \\
\hline Jeoloji $(\mathbf{J})$ & & & & & & & & & & 1 & 0,253 \\
\hline
\end{tabular}


İkili karşılaştırma yönteminde tutarlılık indeksi (CI) değeri 0,1284 olarak hesaplanmıştır. Bunun yanında tutarlılık oranı ise (CR); tutarlılık endeksi (CI) ve ortalama rastgele tutarlılık endeksi (RI) sayıları oranlanarak 0,085 olarak hesaplanmıştır. CR sayısının 0.1' den küçük olması, oluşturulan matrisin tutarlı olduğunu göstermektedir.

\subsection{Atık Depolama Alanlarını Belirlenmesi}

Her kriterin kendi içerisinde sınıflandırılıp 1-6 arası uygunluk değeri verilmesinin ardından, tüm kriterler bu defa kendi arasında ikili karşılaştırma yöntemi kullanılarak ağırlı değerleri belirlenmiş ve son aşamada depolama alanı sonuç haritalarının oluşturulması için ağırlıklı çakıştırma analizi uygulanmıştır. Çakıştırma analizi yapılmadan önce, jeoloji, arazi kullanımı, kuyu, su deposu, yerleşim yeri, yol, akarsu ve eğim kriterleri için uygunluk değeri olarak "1" alan yerler, sınırlı alanlar olarak işaretlenmiş ve analiz işleminin dışında bırakılmışlardır (Şekil 8).

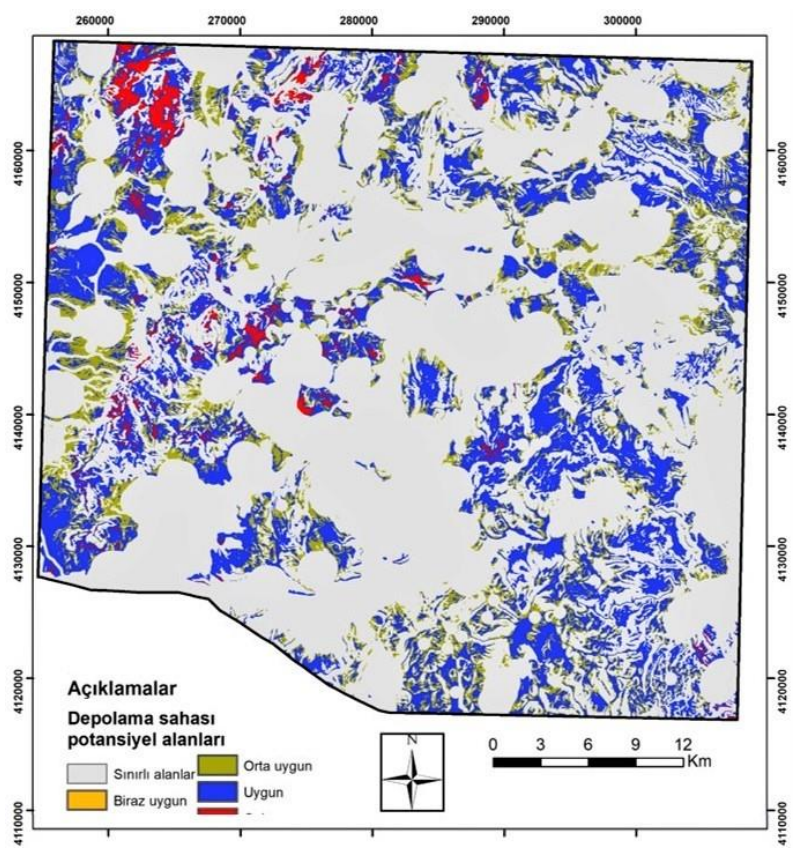

Şekil 8. Mermer atık depolama alanı potansiyel haritası

Elde edilen sonuç haritasına göre, çalışma sahasının \%68' i, depolama alanı için uygun değildir. Analiz işlemi sonunda, "en uygun" şartlarını da sağlayan bir bölge görülmemektedir. Uygun olarak nitelendirilebilecek alanın oranı \%32 iken, "çok uygun" alan olarak bu oran \%2.3 olarak belirlenmiştir ve sahanın orta ve kuzeybatı kesimlerinde yoğunlaştı̆̆ görülmüştür.

\section{Sonuç}

Sürdürülebilir bir çevre için, mermer atıklarının depolanacağı alanların seçiminde doğru kararların verilmesi önemlidir. Geleneksel yöntemler kullanılarak yapılan atık alanı belirleme çalışmaları, oldukça pahalı ve zaman alıcı bir süreçtir. Yapılan çalışmada, CBS ve AHY yöntemi birlikte kullanılarak Bucak ilçesi ve civarında en uygun mermer atık alanlarının belirlenmesine çalışılmıştır. Bu amaçla, yerleşim birimleri, yollar, akarsular, kuyular, su depoları, ocak sahaları, fabrikalar, eğim, arazi kullanımı ve jeoloji olmak üzere toplam 10 kriter değerlendirmede kullanılmıştır. Kriterlerin belirlenmesi ve değerlendirilmesinde ulusal ve uluslararası yönetmelikler ile önceki çalışmalar dikkate alınmıştır. Kriterlerin kendi aralarındaki ağırlık değerlerinin belirlenmesinde AHY yöntemi kullanılmış ve eğim ile jeoloji kriterleri en yüksek; yol ise en düşük ağırlık değerlerini almışlardır. Tüm kriterler raster katmanına dönüştürüldükten sonra yeniden sınıflandırma işlemi uygulanarak 1-6 arasında değişen sınıf aralıklarında değerler atanmıştır. Kriterler kendi aralarında ikili karşılaştırma yöntemi uygulanarak birbirlerine göre önem dereceleri belirlenmiş ve en yüksek puanı alan jeoloji parametresinin en önemli kriter olduğu sonucuna varılmıştır.

Tüm katmanların CBS ortamında yapılan ağırlıklı çakıştırma analizi sonucunda ise çalışma sahasının depolama açısından \%68'lik oranda uygun olmadığı, çok uygun alanların ise \%2.3 olduğu belirlenmiştir. Alan açısından bakıldığında ise bu oran, çalışma sahası içerisinde $26.9 \mathrm{~km}^{2}$ lik bir bölgeye karşılık gelmektedir. En uygun şartları sağlayan bir bölge ise belirlenememiştir.

CBS ve AHY yöntemlerinin birlikte kullanılarak oluşturulan bu çalışma, Bucak ilçesi mermer atık alanlarının belirlenmesinde bir ön çalışma niteliğindedir. Karar alıcı makamlar ve yerel yönetimlere, depolama alanı yer seçimi çalışmalarında sürecin hızlandırılması, maliyetin düşürülmesi ve fikir edinilmesi açısından yardımcı olunması, çalışmanın amacını oluşturur. Depolama alanının yapılacağı yerin seçiminde, son kararın verilmesi için daha ayrıntılı saha çalışmalarının yapılmasının faydalı olacağı düşünülmektedir. 


\section{Kaynakça}

Abdulhasan, M. J., Hanafiah, M. M., Satchet, M. A., Abdulaali, H. S., Toriman, M. E., \& Al-Raad, A. A. (2019). Combining GIS, fuzzy logic and AHP models for solid waste disposal site selection in Nasiriyah, Iraq. Applied Ecology and Environmental Research, 17(3), 6701-6722.

Abdullah, L., \& Adawiyah, C. W. (2014). Simple Additive Weighting Methods of Multi criteria Decision Making and Applications: A Decade Review. International Journal of Information Processing and Management(5), 39-49.

Afzali, A., Sabri, S., Rashid, M., Samani, J. M., \& Ludin, A. N. (2014). Inter-Municipal landfill site selection using Analytic Network Process. Water Resources Management(28), 2179-2194.

Alanbari, M. A., Al-Ansari, N., \& Jasim, H. K. (2014). GIS and multicriteria decision analysis for landfill site selection in AlHashimyah Qadaa. Natural Science(6), 282-304.

Al-Hanbali, A., Alsaaideh, B., \& Kondoh, A. (2011). Using GIS-based weighted linear combination analysis and remote sensing techniques to select optimum solid waste disposal sites within Mafraq City, Jordan. Journal of Geographic Information System(3), 267-278.

Alkaradaghi, K., Ali, S. S., Al-Ansari, N., Laue, J., \& Chabuk, A. (2019). Landfill site selection using MCDM methods and GIS in the Sulaimaniyah Governorate, Iraq. Sustainability, 1-22.

Allen, A. R. (2002). A Cost Effective Landfill Strategy for Developing Countries. Proceedings of 9th Congress of the International Association for Engineering Geology and the Environment, (pp. 136-147). Durban.

Allen, A., Brito, G., Caetano, P., Costa, C., Cummins, V., Donelly, J., . . Vendas, D. (2002). Procedure for the Location of Landfill Sites Using GIS Model. 9th Congress of the International Association of Engineering Geology and the Environment, (p. 100). Durban.

Baban, S. J., \& Flannagan, J. (1998). Developing and implementing GIS-assisted constraints criteria for planning landfill sites in the UK. Planning Practice and Research, 13(2), 139-151. doi:10.1080/02697459816157

Baiocchi, V., Lelo, K., Polettini, A., \& Pomi, R. (2014). Land suitability for waste disposal in metropolitan areas. Waste Management \& Research(32), 707-716.

Beltran, P. A., Fernando, J. P., Garcia, F. G., \& Agullo, A. P. (2010). An analytic network process approach for siting a municipal solid waste plant in the metropolitan area of Valencia (Spain). Journal of Environmental Management, 91(5), 1071-1086.

Chabuk, A. J., Al-Ansari, N., Hussain, H. M., Knutsson, S., \& Pusch, R. (2017). GIS-based assessment of combined AHP and SAW methods for selecting suitable sites for landfill in Al-Musayiab Qadhaa, Babylon, Iraq. Environmental Earth Sciences(76), 1-12.

Chang, N. B., Parvathinathan, G., \& Breeden, J. B. (2008). Combining GIS with fuzzy multicriteria decision making for landfill siting in a Fast-Growing Urban Region. Journal of Environmental Management, 87(1), 139-153. doi:10.1016/j.jenvman.2007.01.002

Delgado, O. B., Mendoza, M., Granados, E. L., \& Geneletti, D. (2008). Analysis of land suitability for the siting of inter-municipal landfills in the Cuitzeo Lake Basin, Mexico. Waste Management, 28(7), 1137-1146. doi:10.1016/j.wasman.2007.07.002

Dimopoulou, E., Tolidis, K., Orfanoudakis, Y., \& Adam, K. (2011). Spatial multi-criteria decision analysis for site selection of sustainable stone waste disposal. Fresenius Environmental Bulletin, 22(7), 1-6.

EC. (2009). Assessing legal compliance with and implementation of the waste acceptance criteria and procedures by the EU-15 anex to the final report. Brussels. Retrieved 09 10, 2019, from https://ec.europa.eu/environment/waste/pdf/report_wac_annexes.pdf

EPA. (2016). Environmental guidelines, solid waste landfills, EPA 2016/0259. Sydney. Retrieved 09 12, 2019 , from https://www.epa.nsw.gov.au/ /media/EPA/Corporate\%20Site/resources/waste/solid-waste-landfill-guidelines-160259.ashx

Gorsevski, P. A., Donevska, K. R., Mitrovski, C. D., Joseph, P., \& Frizado, J. P. (2011). Integrating multicriteria evaluation techniques with geographic information systems for landfill site selection: A case study using ordered weighted average. Waste Management(32), 278-296.

Güler, D., \& Yomralığlu, T. (2017). Alternative suitable landfill site selection using analytic hierarchy process and geographic information systems: a case study in Istanbul. Environmental Earth Sciences, 76(678). doi:10.1007/s12665-017-7039-1

KAG. (2004). Katı Atık Genelgesi (23.06.2004 tarih ve 2004/7 sayılı Çevre ve Orman Bakanlığı Genelgesi). Ankara, Türkiye.

KAKY. (1991). Katı Atıkların Kontrolü Yönetmeliği (14.03.1991 tarih ve 20814 sayılı Resmi Gazetede yayımlanan Çevre Bakanlığı yönetmeliği). Ankara.

Kapilan, S., \& Elangovan, K. (2018). Potential landfill site selection for solid waste disposal using GIS and multi-criteria decision analysis (MCDA). Journal of Central South University(25), 570-585. doi: https://doi.org/10.1007/s11771-018-3762-3

Karadağ, A. A. (2019). Katı atık depolama tesisi yer seçimi için birleştirilmiş hedep programlama ve AHP yaklaşımı. Uluslararası Mühendislik Araştırma ve Geliştirme Dergisi, 11(1), 211-225.

KAUPG. (2011). Düzenli depolama tesisi uygulama projeleri hazırlanmasına ilişkin genelge (01.04.2011 tarih ve 2001/6 sayılı Çevre ve Orman Bakanlığı Genelgesi). Ankara.

Khan, D., \& Samadder, S. R. (2015). A simplified multi-criteria evaluation model for landfill site ranking and selection based on AHP and GIS. Journal of Environmental Engineering and Landscape Managemen, 23(4), 267-278.

Kirimi, F. K., \& Waithaka, E. H. (2014). Determination of suitable landfill site using geospatial techniques and multi-criteria decision analysis: A case study of Nakuru Town. International Journal of Science and Research, 3(11), 500-505.

Kontos, T. D., Komilis, D. P., \& Halvadakis, C. P. (2003). Siting MSW landfills on Lesvos Island with a GIS-based methodology. Waste Management \& Research, 21(3), 262-277. doi:10.1177/0734242X0302100310

Küçükönder, M., \& Karabulut, M. (2007). Çok kriterli analiz yöntemi kullanılarak Kahramanmaraş’ta çöp depolama alanı tespiti. Coğrafi Bilimler Dergisi, 5(2), 55-76.

Lin, H., \& Kao, J. J. (1999). Enhanced spatial model for landfill siting analysis. Journal of Environmental Engineering, 125(9), 845851. doi:dx.doi.org/10.1061/(ASCE)0733-9372 
Lunkapis, J. G., Ahmad, N., Shariff, A. R., Mansor, S., \& Mispan, R. M. (2002). GIS as decision support tool for landfills siting. 2nd World Engineering Congress. Sarawak, Malezya: Faculty of Engineering.

Mahini, S., \& Gholamalifard, M. (2006). Siting MSW landfills with a weighted linear combination (WLC) methodology in a GIS environment. International Journal of Environmental Science and Technology, 3(4), 435-445.

Malczewski, J. (2004). GIS-based land use suitability analysis: A critical overview. Progress in Planning, 62(1), 3-65.

MAY. (2015). Maden Atıkları Yönetmeliği (15.07.2015 tarih ve 29417 sayılı Resmi Gazedede yayımlanmış Çevre ve Şehircilik Bakanlığı Yönetmeliği). Ankara.

Randazzo, L., Cusumano, A., Oliveri, G., Di Stefano, P., \& Renda, P. (2018). Landfill site selection for municipal solid waste by using AHP method in GIS environment: Waste management decision-support in Siclly (Italy). Multidisiplinary Journal For Waste Resources and Residues(2), 78-88.

Rezaei-Moghaddam, K., \& Karami, E. (2008). A multiple criteria evaluation of sustainable agricultural development models using AHP. Environment Development and Sustainability(10), 407-426.

Saaty, T. L. (1980). The analytic hierarchy process. New York: McGraw Hill.

Sancar, C. (2000). Kentsel gelişim alanlarının saptanmast ve planlanmasinda CBS ve ekoloji-ekonomi duyarl planlama modeli. Trabzon: Karadeniz Teknik Üniversitesi, Fen Bilimleri Enstitüsü (Yayımlanmamış).

Siddiqui, M. Z., Everett, J. W., \& Vieux, B. E. (1996). Landfill siting using geographic information systems: A demonstration. Journal of Environmental Engineering, 122(6), 515-523. doi:http://dx.doi.org/10.1061/(ASCE)0733-9372

Soyaslan, İ. İ., Hepdeniz, K., \& Konu, A. (2011). Bucak mermer atık envanterinin çıkarllması. Isparta: Batı Akdeniz Kalkınma Ajansı, Sonuç Raporu (Proje No: TR61/11/DFD/17).

Şener, B. (2004). Landfill site selection by using GIS. Ankara: Orta Doğu Teknik Üniversitesi, Fen Bilimleri Enstitüsü (Yayımlanmamış).

Şengün, M. T., Siler, M., \& Engin, F. (2018). Katı atık depolama alanlarının yer seçiminde CBS'nin kullanımı: Malatya Örneği. ZEITSCHRIFT FÜR DIE WELT DER TÜRKEN (ZfFT)/ JOURNAL OF WORLD OF TURKS, 159-180.

TMMOB. (2014). Burdur Gölü havzası mermer ocakları raporu. Ankara: Türk Mühendis ve Mimarlar Odaları Birliği.

URL-1. (2019). Retrieved 09 30, 2019, from T.C. Bucak Kaymakamlı̆̆1: http://www.bucak.gov.tr/bucak-nufus

USEPA. (2003). Location criteria chapter 2 Sub-Part B: In solid waste disposal facility criteria: Technical Manual. Washington: United States Environmental Protection Agency (USEPA 530-R-93).

Vasiljevic, T. Z., Srdjevic, Z., Bajcetic, R., \& Miloradov, V. M. (2012). GIS and the analytic hierarchy process for regional landfill site selection in transitional countries: A case study from Serbia. Environmental Management(49), 445-458. doi:10.1007/s00267-0119792-3

Yazdani, M., Monavari, S. M., Omrani, G. A., Shariat, M., \& Hosseini, S. M. (2015). Landfill site suitability assessment by means of geographic information system analysis. Solid Earth(6), 945-956. doi:10.5194/se-6-945-2015

Yıldırım, Ü., \& Güler, C. (2016). Identification of suitable future municipal solid waste disposal sites for the Metropolitan Mersin (SE Turkey) using AHP and GIS techniques. Environmantel Earth Sicences, 75(101). doi: 10.1007/s12665-015-4948-8

Yılmaz, E. (2005). Analitik Hiyerarşi Süreci Kullanarak Katılımcı Doğal Kaynak Planlaması, T.C. Çevre ve Orman Bakanlığı Doğu Akdeniz Ormancıllk Araş̧ırma Enstitüsü. Tarsus: Çevre ve Orman Bakanlığı Yayın No: 238 ISSN: 1300-7912 DOA Yayın No:31.

Ying, X., Guang-Ming, Z., Gui-Qiu, C., Ke-Lin, W., \& Dao-You, H. (2007). Combining AHP with GIS in synthetic evaluation of ecoenvironment quality: A case study of Human Province, China. Ecological Modelling, 209(2-4), 97-109.

Yoon, K., \& Hwang, C. L. (1995). Multiple Attribute Decision Making: an Introduction. London: Sage Publication Inc., 83 p.

Zulu, S., \& Jerie, S. (2017). Site suitability analysis for solid waste landfill site location using Geographic Information Systems and Remote Sensing: A case study of Banket Town Board, Zimbabwe. Review of Social Sciences, 2(4), 19-31. 